Shwachman and Gahm (1956) reported a simple application of the basic principles of the sweat test, incorporating chemicals in an agar base to assess the salt content of the sweat in the fingerprint. They suggest this variation of the test may produce positive results as early as the third week of life. This preliminary communication records our experiences with this ingenious method which entails no risk.

\section{Method and Results}

The medium is prepared by adding to $500 \mathrm{ml}$. of normal agar base $4.2 \mathrm{~g}$. of silver nitrate and $2.4 \mathrm{~g}$. of potassium chromate, both chemicals being thoroughly mixed on addition. Plates are poured, and storage at $4^{\circ} \mathrm{C}$. appears to preserve the medium for periods of up to a few weeks. The salt in the sweat produces bleaching of the suspended chromate, and the result can be read, as was suggested by Shwachman and Gahm, as,+++ , or +++ . By testing a known case of fibrocystic disease and a series of normal children, these differentiations are readily learned. A fingerprint from the unwashed hand is taken as a "baseline" and further prints are made $5,10,15$, and 20 minutes after thoroughly rinsing the hands in warm running water to remove any accumulated salt, care being taken to avoid excessive handling by the fingers during the waiting period. A different finger should be used for each impression. No attempt to control the temperature of the room seems to be necessary: it is sufficient that the room be reasonably warm.

To date, 54 cases of known fibrocystic disease have been tested by this method. All gave a +++ reaction in the unwashed print. After washing, 15 showed a similar reaction in 5 minutes, 45 in 10 minutes, 51 in 15 minutes, while all 54 gave a +++ reaction only after a full 20 minutes. Of the number tested one infant was 4 weeks of age, 6 more were less than 6 months, while 14 others were less than 1 year. The result of the fingerprint test has been confirmed in $\mathbf{4 6}$ cases so far tested by finding raised electrolyte levels in the sweat obtained from the full sweat technique 8 of the 54 remain to be tested. These preliminary results are in complete agreement with the larger series investigated by Shwachman and Gahm and reported in their article. Of their 140 cases, all but two gave a +++ reaction, while in one of the two giving a ++ reaction the full sweat test showed normal sweat electrolytes, the other giving the elevated figures normally found in fibrocystic disease. In a series of nearly 200 " normal " children of the same age group tested as controls no false positives have been encountered.

It is thought, therefore, that this fingerprint method offers a simple and probably very reliable screening test for cases of fibrocystic disease. A negative test, however, in the first few weeks of life does not necessarily exclude the diagnosis. The larger-scale investigations at present being undertaken may show the full sweat test to be unnecessary, and, it is hoped, prove the almost complete specificity of the test. At the least, it seems to obviate the necessity of performing the sweat test in full in small babies.

REFERENCE

Shwachman, H., and Gahm, N. (1956). New Engl. J. Med., 255, 999.

The Scientific Film Association, in collaboration with the London University Institute of Education, has recently issued a catalogue of films on psychology and psychiatry. This catalogue is a revised edition of the S.F.A. catalogue of films on psychology (1953), and includes films made available since that date. The size and duration of each film are given, together with a brief description of its content and the type of audience for which it is thought suitable. The catalogue (price 5s. net) is obtainable from the Scientific Film Association, 164, Shaftesbury Avenue, London, W.C.2.

\section{A LONG-ACTING INHIBITOR OF GASTRIC SECRETION}

BY

\author{
A. H. DOUTHWAITE, M.D., F.R.C.P. \\ Senior Physician, Guy's Hospital, London
}

J. N. HUNT, M.D., D.Sc.

Reader, Physiology Department, Guy's Hospital Medical School

AND

I. MACDONALD, Ph.D., M.B., B.S.

Lecturer, Physiology Department, Guy's Hospital Medical School

This is a preliminary report on (1-methyl-2-pyrrolidyl) methyl benzilate methyl methosulphate (IS 499), a substance having atropine-like properties, which promises to be useful in reducing the gastric secretion of acid in patients with peptic ulcer. Chemical and pharmacological details will be published shortly (Doyle et al., 1957 ; Acred et al., 1957).

\section{Present Investigation}

Twenty-four oral doses of IS 499 varying between 5 and $20 \mathrm{mg}$. were given to five normal subjects, and the salivary flow was measured from collections with a dental aspirator. Doses of $10 \mathrm{mg}$. taken by mouth partly inhibited salivary flow after a latent period of two hours, but the maximal effect was not reached until about four hours after taking the drug. The reduction in salivary flow lasted from seven to nine hours. With doses of 15 to $20 \mathrm{mg}$. the only other effects were tachycardia and slight difficulty in micturition. The unusually long duration of action of IS 499 was an encouraging feature which made it worth while to test the effect of the drug on gastric secretion.

Seven normal subjects were given a total of 98 test meals lasting 30 minutes by a technique which allows the amounts of acid secreted in response to the meal to be calculated. The tests also gave information about the volume of meal remaining in the stomach after 30 minutes (Hunt, 1954). For each subject the response to the meal without any drug was determined several times during the period of the tests. Doses of the drug varying between 1 and $20 \mathrm{mg}$. were given either at 11 p.m. or at 5 a.m., before the tests were made at 8 a.m., so that two dose-response curves were made for each person. It was found that doses of 1 or $2 \mathrm{mg}$. given at $5 \mathrm{a} . \mathrm{m}$. or $2.5 \mathrm{mg}$. at $11 \mathrm{p} . \mathrm{m}$. reduced the secretion of acid in response to the test meal. The Table shows the results of tests in the seven normal subjects and in five patients with peptic ulcer. In 8 out of 12 persons the

Percentage Inhibition of Secretion of Acid at 8 a.m. by Doses of IS 499 Given at 11 p.m. or 5 a.m.

\begin{tabular}{|c|c|c|c|c|c|}
\hline \multirow{2}{*}{ Subject } & \multirow{2}{*}{ Diagnosis } & \multicolumn{2}{|c|}{ Percentage Inhibition } & \multirow{2}{*}{$\begin{array}{l}\text { No. of } \\
\text { Tests }\end{array}$} & \multirow{2}{*}{$\begin{array}{c}\text { Control } \\
\text { Secretion of } \\
\text { Acid (ml. } \\
0 \cdot 16 \mathrm{~N} \mathrm{HCl} \text { )/ } \\
30 \mathrm{~min} .\end{array}$} \\
\hline & & $\begin{array}{c}5 \mathrm{mg} . \\
\text { at } 5 \mathrm{a} . \mathrm{m} .\end{array}$ & $\begin{array}{c}10 \mathrm{mg} . \\
\text { at } 11 \mathrm{p.m} .\end{array}$ & & \\
\hline \multirow[t]{2}{*}{$\begin{array}{l}\mathbf{P} \\
\mathbf{H} \\
\mathbf{W} \\
\mathbf{L} \\
\mathbf{M} \\
\mathbf{Q} \\
\mathbf{T} \\
\mathbf{H} \\
\mathbf{C}\end{array}$} & $\begin{array}{c}\text { Normal } \\
\text {," } \\
\text { ", } \\
\text { ", } \\
\text { Prepyloric ulcer } \\
\text { Duodenal ", }\end{array}$ & $\begin{array}{r}60 \\
40 \\
5 \\
40 \\
40 \\
60 \\
-60 \\
20\end{array}$ & $\begin{array}{r}50 \\
10 \\
50 \\
30 \\
10 \\
40 \\
60 \\
-30 \\
-10\end{array}$ & $\begin{array}{r}16 \\
24 \\
10 \\
8 \\
6 \\
20 \\
14 \\
3 \\
4\end{array}$ & $\begin{array}{r}40 \\
24 \\
34 \\
14 \\
128 \\
76 \\
77 \\
77 \\
36 \\
39\end{array}$ \\
\hline & & & $\begin{array}{l}8 \mathrm{mg} . \text { at } \\
11 \mathrm{p.m} .\end{array}$ & & \\
\hline $\begin{array}{l}\mathbf{B} \\
\mathbf{R} \\
\mathbf{G}\end{array}$ & $\begin{array}{l}\text { Duodenal ulcer } \\
\text { Gastric } \\
\text { Duodenal " }\end{array}$ & $\begin{array}{l}60 \\
50 \\
50\end{array}$ & $\begin{array}{l}60 \\
50 \\
30\end{array}$ & $\begin{array}{l}\mathbf{3} \\
\mathbf{3} \\
\mathbf{3}\end{array}$ & $\begin{array}{r}91 \\
37 \\
139\end{array}$ \\
\hline
\end{tabular}


secretion of acid was $40-60 \%$ inhibited by the $5-\mathrm{mg}$. dose given three hours before the test. In 6 out of the 12 persons the secretion of acid was $40-60 \%$ inhibited nine hours after a dose of 10 or $8 \mathrm{mg}$. The output of the alkaline secretions of the gastric mucosa was usually not reduced, but gastric emptying was somewhat slowed. With doses up to $10 \mathrm{mg}$. there were no troublesome side-effects, the reduction of salivary flow not being noticed by the subjects if it occurred.

Clinical trials of this drug, which in low doses by mouth has a selective action of long duration on the gastric secretion of acid, are now being undertaken with a view to controlling secretion of acid in patients with duodenal ulceration.

We wish to thank our students who took part in the tests; the members of the clinical staff who allowed us to investigate their patients; and Beecham Research Laboratories Ltd. for the supply of IS 449 .

\section{REFERENCES}

Acred, P., Bainbridge, J. G., Brown, D. M., Quinton, R. M., and Turner, D. H. (1957). In preparation.

Doyle. F. P., Mehta, M. D., Sach, G. S., and Pearson, J. (1957). In preparation.

Hunt. J. N. (1954). Guy's Hosp. Rep., 103, 161

\section{Medical Memoranda}

\section{Agranulocytosis with Recovery During Promazine Therapy}

Promazine, one of the newer ataractic drugs, has recently been introduced for the treatment of certain types of mental illness. Like chlorpromazine it is a phenothiazine derivative, but differs from chlorpromazine in that the chlorine atom is absent from its structure. Agranulocytosis has been recorded during the course of chlorpromazine treatment (Goldman, 1955), and we record below details of a case under our care in which this complication occurred during promazine therapy.

\section{CASE Report}

The patient, a woman aged 60 , was admitted to hospital on March 26, 1957. A severe depressive illness had been present for five months and there were features of considerable anxiety, with restlessness. Physical examination revealed nothing of importance with the exception of moderate hypertension (B.P. $190 / 110 \mathrm{~mm}$. $\mathrm{Hg}$ ). There was no anaemia. The W.B.C. count was 6,000 per c.mm. Sedation with amylobarbitone sodium was not effective and was discontinued. On April 2 promazine treatment was begun with $100 \mathrm{mg}$. thrice daily, and the dose was increased on April 4 to $200 \mathrm{mg}$. thrice daily. Thereafter the excitement and agitation were observed to diminish. In the ensuing weeks regular white-cell counts fluctuated from 5,000 to 8,000 per c.mm. A representative differential white cell count was: neutrophil polymorphs $62 \%$, neutrophil stab cells $2 \%$, eosinophils $2 \%$, lymphocytes $27 \%$, monocytes $7 \%$.

On April 27 the patient complained of sore throat. There was no fever, and on inspection the throat appeared healthy. On April $29^{2}$ the temperature rose to $100.6^{\circ} \mathrm{F}$. $\left(38.1^{\circ} \mathrm{C}\right.$.), the fauces were noted to be inflamed and oedematous, and cervical adenitis appeared. Blood examination revealed a complete neutropenia: W.B.C., 1,900 per c.mm. (lymphocytes $48 \%$, monocytes $52 \%$ ); Hb, 11 g. $/ 100 \mathrm{ml}$.; platelets, 316,000 per c.mm. Sternal marrow examination yielded only a few islets of fatty tissue with no cellular areas.

Promazine administration was discontinued and 1 mega unit of crystalline penicillin was given twelve-hourly. Daily differential white-cell counts were performed. Corticotrophin gel was given intramuscularly in dosage of $50 \mathrm{mg}$. twelve-hourly from May 3, and on May 4, for the first time for six days, a differential count done on a buffy film showed
$2 \%$ of neutrophil stab cells: segmented polymorphs remained absent. On May 51 pint $(570 \mathrm{ml}$.) of fresh blood was transfused. Each ensuing day thereafter was associated with a gradual increase in the proportion of neutrophil polymorphs in the peripheral blood, and by May 13 the white-cell count was 11,850 per c.mm. (neutrophil polymorphs $86 \%$; neutrophil stab cells $6 \%$, lymphocytes $5 \%$, monocytes $3 \%$ ). Clinical recovery from the agranulocytic episode was then complete, and corticotrophin and penicillin were withdrawn.

\section{COMMENT}

Agranulocytosis complicating promazine therapy has been reported on one previous occasion (Woodward and Solomon, 1956), and in that case proved fatal. This patient also was a middle-aged woman, and dosage had been instituted at $100 \mathrm{mg}$. a day, increasing to $1,000 \mathrm{mg}$. a day over a 42 day period. In contrast to our patient, lymphocytes rather than monocytes had predominated in the peripheral blood during the agranulocytic period, and this is said to indicate a worse prognosis (Whitby and Britton, 1953). It is clear that serious depression of the red bone marrow can occur following both promazine and chlorpromazine administration, and vigilance during their use remains essential.

We wish to thank Professor T. Ferguson Rodger for permission to publish this case.

\section{A. Cook, M.B., Ch.B.}

A. G. Melrose, M.D., F.R.F.P.S., M.R.C.P.Ed.

J. R. RoY, M.B., F.R.F.P.S., M.R.C.P.Ed. The Southern General Hospital, Glasgow.

\section{REFERENCES}

Goldman, D. (1955). J. Amer. med. Ass., 157, 1274.

Whitby, L. E. H., and Britton, C. J. C. (1953). Disorders of the Blood, 7th ed. Churchill, London.

Woodward, D. J., and Solomon, J. D. (1956). J. Amer. med. Ass., 162, 1308.

\section{A Case of Carcinoid Tumour}

The general features of carcinoid tumour, with the effects of the substance hydroxytryptamine (5-H.T.) which is secreted by the tumour cells, were described in the British Medical Journal (1956). A clinical report of such a case exhibiting many of the classical signs and symptoms of the syndrome is given below. The patient is still alive despite a history dating back for at least eight years.

\section{Case Report}

A woman now aged 71 first came under observation in 1949. She was married and had borne four children. The previous medical history was irrelevant until 1948, when she had attacks of abdominal discomfort and flatulence for which her gall-bladder was removed without more than temporary relief.

In 1949 she suffered from definite abdominal pains which were periumbilical, colicky, and intermittent, occurring in attacks at irregular intervals and lasting between 6 and 24 hours. Many such attacks were witnessed during the succeeding four years. They were often associated with a low fever, loose stools, and occasional vomiting, and were succeeded by a few days' anorexia and malaise. During the colicky phases abdominal examination was negative, but during the ensuing days tenderness which slowly disappeared was present in the right iliac fossa. In all other respects clinical examination was negative and her general health and nutrition remained good. Barium meal, barium enema, and stool tests were carried out with negative results. A tentative diagnosis of recurring mild appendicitis was expressed, but in view of the diarrhoea and the absence of maintained pain during the attacks this was not made with great conviction.

The patient was admitted to hospital in March, 1953, as a case of subacute intestinal obstruction. Investigations failed to add light on the diagnosis, and it was decided to perform an exploratory laparotomy on March 17. The 